WHOI $-81-32$

\title{
STATISTICAL MECHANICS OF GEOMAGNETIC ORIENTATION IN SEDIMENT BACTERIA
}

by

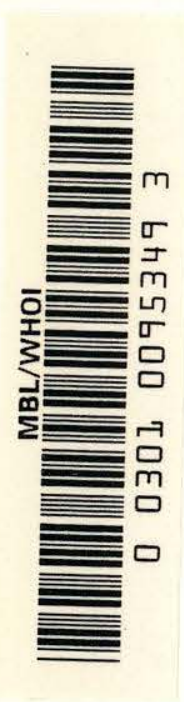

\author{
Michael K. Gilson \\ and \\ Ad. J. Kalmijn \\ WOODS HOLE OCEANOGFAPHIC INSTITUTION \\ Woods Hole, Massachusetts 02543
}

Apri1 1981

TECHNICAL REPORT

Prepared for the Office of Naval Research under Contract N00014-79-C-0071.

Reproduction in whole or in part is permitted for any purpose of the United States Govemment. In citing this report in a bibliography, the reference given should be to: The Biological Bulletin 159(2): 459-460 (October 1980).

Approved for public release; distribution unlimited.

Approved for Distribution: George D. Grice, Chairman Department of Biology 
Reprinted from The Biological Bulletin, Vol. 159, No. 2, pp. 459-460, October 1980

Printed in U. S. A.

Statistical mechanics of geomagnetic orientation in sediment bacteria. MichaeL K. Gilson and Ad. J. Kalmijn.

Last year we reported on time-of-transit experiments in which magnetically orienting bacteria crossed a $1-\mathrm{mm}$ stretch in the direction of a uniform magnetic field. The bacteria were found to behave as tiny self-propelled compass needles subject both to magnetic field alignment and to the randomizing effect of thermal agitation. In strong fields, magnetic bacteria are held in tight alignment; in weaker fields, their swimming paths meander more and transit times are greater. Paul Langevin derived an expression for the distribution of orientation in an ensemble of free-moving dipole particles as a function of ambient field strength. His theory becomes applicable to our experiments when bacterial migration is analyzed as a sequence of short steps during each of which the cell swims in a direction randomly selected from the Langevin distribution. The duration of each step, $\Delta t$, is actually a time constant of the cell's loss of directionality due to thermal agitation. By thus treating the migration as a process of random walk with drift, we are able to predict the mean and variance of the time of transit across a $1-\mathrm{mm}$ stretch. The behavior of the model depends on three parameters: the randomization time $\Delta t$, the cell's intrinsic dipole moment $\mathrm{m}$, and the speed of propulsion $\mathrm{V}_{0}$. We use nonlinear regression analysis to estimate these parameters and to fit the behavior of the model to that of the bacteria. We also determine the goodness of fit of the model in its entirety, and the approximate confidence limits of the parameter estimates. The estimated randomization times are in accord with preliminary calculations of rotational diffusion rates. The dipole strengths agree well with those expected on the basis of the number and size range of the bacteria's intracellular magnetite crystals. Our values are slightly lower due to the inevitable impurities and imperfections in alignment of the crystals, and to additional agitation resulting from swimming movements. In short, the dipole moments direct the bacteria magnetically despite thermal agitation and swimming noise. As statistical mechanics suffice to explain the orientation of magnetic bacteria, there is no need to invoke an active orientation mechanism.

(Kalmijn's project on electric and magnetic detection uperates under the auspices of the Office of Naval Research, Oceanic Biology Program, N00014-79-C-0071.) 
MANDATORY DISTRIBUTION LIST

FOR UNCLASSIFIED TECHNICAL REPORTS, REPRINTS, AND FINAL REPORTS PUBLISHED BY OCEANOGRAPHIC CONTRACTORS

OF THE OCEAN SCIENCE AND TECHNOLOGY DIVISION

OF THE OFFICE OF NAVAL RESEARCH

(REVISED NOVEMBER 1978)

1 Deputy Under Secretary of Defense

(Research and Advanced Technology)

Military Assistant for Environmental Science Room 3D129

Washington, D.C. 20301

Office of Naval Research

800 North Quincy Street

Arlington, VA 22217

3 ATTN: Code 483

1 ATTN: Code 460

2 ATTN: 102B

1 CDR J. C. Harlett, (USN)

ONR Representative

Woods Hole Oceanographic Inst.

Woods Hole, MA 02543

Commanding officer

Naval Research Laboratory

Washington, D.C. 20375

6 ATTN: Library, Code 2627
12 Defense Documentation Center Cameron Station

Alexandria, VA 22314

ATTN: DCA

Commander

Naval Oceanographic Office NSTL Station

Bay St. Louis, MS 39522

1 ATTN: Code 8100

1 ATTN: Code 6000

1 ATTN: Code 3300

1 NODC/NOAA

Code D781

Wisconsin Avenue, N.W.

Washington, D.C. 20235 
UNCLASSIFIED $4 / 81$

SECURITY CLASSIFICATION OF THIS PAGE (When Data Entered)

\begin{tabular}{|c|c|}
\hline REPORT DOCUMENTATION PAGE & $\begin{array}{l}\text { READ INSTRUCTIONS } \\
\text { BEFORE COMPLETING FORM }\end{array}$ \\
\hline \begin{tabular}{l|l|} 
1. REPORT NUMBER & 2. GOVT ACCESSION NO. \\
WHOI $-81-32$ &
\end{tabular} & 3. RECIPIENT'S CATALOG NUMBER \\
\hline \multirow[t]{2}{*}{$\begin{array}{l}\text { 4. TITLE (and Subtitie) } \\
\text { STATISTICAL MECHANICS OF GEOMAGNETIC ORIENTATION } \\
\text { IN SEDIMENT BACTERIA }\end{array}$} & $\begin{array}{l}\text { 5. TYPE OF REPORT A PERIOD COVERED } \\
\text { Technical }\end{array}$ \\
\hline & 6. PERFORMING ORG. REPORT NUMBER \\
\hline $\begin{array}{l}\text { 7. AuThOR(o) } \\
\text { Michael K. Gilson and Ad J. Kalmijn }\end{array}$ & $\begin{array}{l}\text { 8. CONTRACT OR GRANT NUMBER(a) } \\
\text { N00014-79-C-0071 }\end{array}$ \\
\hline $\begin{array}{l}\text { 9. PERFORMING ORGANIZATION NAME AND ADDRESS } \\
\text { Woods Hole Oceanographic Institution } \\
\text { Woods Hole, Massachusetts } 02543\end{array}$ & $\begin{array}{l}\text { 10. PROGRAM ELEMENT, PROJECT, TASK } \\
\text { AREA \& WORK UNIT NUMBERS }\end{array}$ \\
\hline \multirow{2}{*}{$\begin{array}{l}\text { 11. CONTROLLING OFFICE NAME AND ADDRESS } \\
\text { NORDA/National Space Technology Laboratory } \\
\text { Bay St. Louis, MS } 39529\end{array}$} & $\begin{array}{l}\text { 12. REPORT DATE } \\
\text { April } 1981\end{array}$ \\
\hline & 13. NUMBER OF PAGES \\
\hline \multirow[t]{2}{*}{ 14. MONITORING AGENCY NAME \& ADDRESS(if differont from Controllind Office) } & $\begin{array}{l}\text { 15. SECURITY CLASS. (of thio roport) } \\
\text { Unclassified }\end{array}$ \\
\hline & $\begin{array}{l}\text { 15a. DECLASSIFICATION/DOWNGRADING } \\
\text { SCHEDULE }\end{array}$ \\
\hline
\end{tabular}

Approved for public release; distribution unlimited.

17. DISTRIBUTION STATEMENT (of the abotract ontered in Block 20, if difforent trom Roport)

18. SUPPLEMENTARY NOTES

Reprinted from: The Biological Bulletin 159(2): 459-460 (0ctober 1980).

19. KEY WORDS (Continue on reverse eide if noceseary and identify by block number)

1. Statistical mechanics

2. Geomagnetic orientation

3. Sediment bacteria

20. ABSTRACT (Continue on revereo oldo if noceeseary and identify by block number)

Last year we reported on time-of-transit experiments in which magnetically orienting bacteria crossed a $1-\mathrm{mm}$ stretch in the direction of a uniform magnetic field. The bacteria were found to behave as tiny self-propelled compass needles subject both to magnetic field alignment and to the randomizing effect of thermal agitation. In strong fields, magnetic bacteria are held in tight aligment; in weaker fields, their swimming paths meander more and transit times are greater.

(continued on back) 
20.

Paul Langevin derived an expression for the distribution of orientation in an ensemble of free-moving dipole particles as a function of ambient field strength. His theory becomes applicable to our experiments when bacterial migration is analyzed as a sequence of short steps during each of which the cell swims in a direction randomly selected from the Langevin distribution. The duration of each step, $\Delta t$, is actually a time constant of the cell's loss of directionality due to thermal agitation. By thus treating the migration as a process of random walk with drift, we are able to predict the mean and variance of the time of transit across a 1-mm stretch. 
Woods Hole Oceanographic Institution

| STATISTICAL MECHANICS OF GEOMAGNETIC ORIENTATION IN
SEDIENT BACTERIA SEDIMENT BACTERIA by Michael $\mathrm{K}$. Gilson and Ad. J. Kalmijn. April 1981. Prepared for the
under Contract N00014-79-C-0071.

1

Last year we reported on time-of-transit experiments in which magntically orienting bacteria crossed a 1 -mm stretch
in the direction of a uniform magnetic field. The bacteria were found to behave as tiny self-propelled compass needles were found to behave as tiny self-propelled compass needies
subject both to magnetic field alignment and to the randomizing affect on thernal agitation. In strong fields, magnetic bacteria are held in tight alignment; in weaker fields, greater. Paul pangevin derived an expression for the dis. tribution of orientation in an ensemble of free-moving dipole particles as a function of ambient field strength. terial during each of which the cell swims in a direction randomly selected from the Langevin distribution. The duration of each step, $\Delta t$, is actually a time constant of the cell's drift, we are able to predict the mean and variance of the

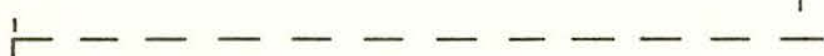

Woods Hole Oceanographic Institution

1

STATISTICAL MECHANICS OF GEOMAGNETIC ORIENTATION IN SEDIMENT BACTERIA by Michael K. Gilson and Ad. J. Kalmijn.

under Contract N00014-79-C-0071.

।

Last year we reported on time-of-transit experiments Which magntically orienting bacteria crossed a 1-mm stretch in the direction of a uniform magnetic field. The bacteri were subject both behave as tiny self-propelled compass needles ing piffect on thermal agitation. In strong fields, magnetic bacteria are held in tight alignment; in weaker fields, their swiming paths meander more and transit times are tribution of orientation in an ensemble of free-moving dipole particles as a function of ambient field strength. terial oryation is analyzed as a seguence of short staps during each of which the cell swims in a direction randomly selected from the Langevin distribution. The duration of each step, $\Delta t$, is actualty a time constant of the cell ss drift, we are able to predict the mean and variance of the time of transit across a $1-\mathrm{rm}$ stretch.
1. Statistical mechanics

2. Geomagnetic orientation

3. Sediment bacteria

I. Gilson, Michael $\mathrm{x}$

II. Kalmijn, Ad. J.

III. N00014-79-C-0071

This card is UNCLASSIFIED

1. Statistical mechanics
2. Geomagnetic orientation
3. Sediment bacteria
I. Gilson, Michael K.
II. Kalmijn, Ad. J.

III. N00014-79-C-0071

This card is UNCLASSIFIED

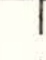

1

ods Hole Oceanographic Institution
$01-81-32$

SEDIMENT BACTERIA by Michael K. Gilson and Ad J. Kalmi ijn.

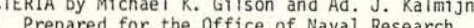

der Contract N00014-79-C-0071.

Last year we reported on time-of-transit experiments in which magntically orienting bacteria crossed a 1-m stretch in the direction of a uniform magnetic field. The bacteria
were found to behave as tiny self-propelled compass needles were found to behave as tiny self-propelled compass needles
subject both to magnetic field alignment and to the randormizing effect on thernal agitation. In strong fields, magnetic bacteria are held in tight alignnent; in weaker fields, their swiaming paths meander more and transit times are tribution of orientation in an ensentes of freeroving dispole particles as a function of ambient field strength. ins theory becomes applicable to our experiments when bacduring selected from the Langevin distribution, The duration of each step, $\Delta t$, is actually a time constant of the cell's treating the migration as a to the rmal agitation. By thus drift, we are able to predict the mean and variance of the

time of transit across a 1-mm stretch.

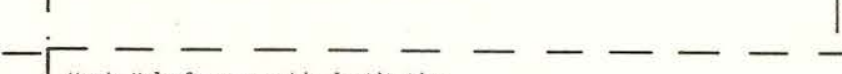

Woods Hole Oceanographic Institution

\section{1}

STATISTICAL MECHANICS OF GEOMAGNETIC ORIENTATION IN SEDIMENT BACTERI by Michae K. Gilson and Ad. J. Kalmijn.
April 1981. Prepared for the Office of Naval Research
under Contract No0014-79-C-0071.

Last year we reported on time-of-transit experiments in which magntically orienting bacteria crossed a l-min stretch
in the direction of a uniform magnetic field. The bacteria were found to behave as tiny self-propelled compass needles subject both to magnetic field alignment and to the randomiz ing pectect on thermal agitation. In strong fields, magnet-
bacteria are held in tight alignment; in weaker fields. their swimming paths meander more and transit times are greater. Paul Langevin derived an expression for the dis tribution of orientation in an ensemble of free-mioving di-
pole particles as a function of ambient field strength. poie particles as a function of ambient field strength. terial migration is analyzed as a sequence of short steps during each of which the cell swims in a direction randomly
selected from the Langevin distribution. The duration of selected from the Langevin distribution. The duration of
each step, $\Delta t$, is actually a time constant of the cell's loss of directionality due to thermal agitation. treating the migration as a process of random waik with drift, we are able to predict the mean and variance of the
Statistical mechanics

2. Geomagnetic orientation

3. Sediment bacteria

I. Gilson, Michael $\mathrm{K}$.

II. Kalmijn, Ad. J.

III. N00014-79-C-0071

This card is UNCLASSIFIED

1. Statistical mechanics

2. Geomagnetic orientation

3. Sediment bacteria

I. Gilson, Michael $\mathrm{K}$.

II. Kalmijn, Ad. J.

III. N00014-79-C-0071

This card is UNCLASSIFIE 